\title{
Analysis Of The Factors That Influence The Achievement Of K1 In The Working Area at The Tirtoyudo Community Health Center
}

Andariningsih
Magister of Public Health Program of
Institut Ilmu Kesehatan STRADA
Indonesia
Email:
bundari124@gmail.com

Received : October 12, 2019

Accepted : February 13, 2020

Published : May 12, 2020

\begin{abstract}
The problem of maternal death is still a major problem in the health sector. The health of a pregnant women is an important aspect to consider in a women's life cycle because during her pregnancy there can be unexpected complications. Pregnancy checks should be done as early as possible, as soon as a woman feels she is pregnant. The purpose of the study was to determine the effect of partial and silmutan between the pregnant women's knowledge, husbands support, and the role of cadres on the level of achievement of $\mathrm{K} 1$ in the work area at the health center of Tirtoyudo. The research design used is quantitative research using "explanatory research. The sampling technique used is "proportional sampling" of 105 respondents. This study uses a survey method using a questionnaire that contains statements and the collection of dats by interview and questionnaire, then in the measurement technique of research data using a Likert scale. Likert scale has a gradation from very positive to very negative to four levels. Instruments that both must meet two requirements is important is valid and reliable. Validity is the level of reliability and validity of the tool measuring are used, while the test of reliability is useful to establish whether the instrument, in terms of this questionnaire, can be used more than one time, at least not by the respondents are the same and will generate data consistent. Results The study showed that 1) the knowledge Ibu Hamil has the effect of the positive and signiikan against keputusanIbu Pregnant To do Visits First (K1) three months of the first period of pregnancy ,2) support of husband does not have the effect that is significant to the decision of the mother pregnant to do the visit first (K1) three months of the first period of pregnancy and 3) the role of the CadreHealth has the effect that a positive and significant to the decision of the mother pregnant to do the visit first (K1) three months of the first period of pregnancy
\end{abstract}

Keywords: Public Health Centre, Achievement K1, Mother Pregnant 
This is an open-acces article distributed under the terms of the Creative Commons Attribution-ShareAlike 4.0 International License.

\section{INTRODUCTION}

In Indonesia the problem of maternal death is also still a major problem in the health sector. Mothers have a high risk during childbirth in several countries, especially developing countries and developing countries. In Indonesia the maternal mortality rate is among the highest in the Southeast Asian region. According to UNESCAP data the maternal mortality rate in Indonesia is 220 / 100.00 live births. This figure is the fourth highest death rate among countries in Southeast Asia. Based on Indonesia's Demographic and Health survey in 2012, the maternal mortality rate (MMR) related to pregnancy, childbirth and childbirth was 359 / 100,000 live births. The target of reducing MMR in Indonesia in 2015 is 102 per 100,000 live births.

The high maternal mortality rate in Indonesia is related to the low quality of various programs in efforts to reduce the MMR that has been implemented by the government such as Safe Motherhood (SM), which is known to be the four pillars of: family planning, antenatal care, clean delivery, and handling of the postpartum period, followed by the MPS program i.e. childbirth by health workers, overcoming complications, prevention of unwanted pregnancies and handling of miscarriage complications through strategies, namely: (1) all districts / cities as effective units in gradually increasing the service of the MCH program, implementing quality control, among others through AMP in their area or involving other regencies / cities (across borders),(2) District / city Health Office functions as a coordinator in collaboration with district / city hospitals and involves puskesmas and other private MCH services in quality control efforts in district / city areas, (3) at the district / city level it is necessary to establish an AMP team which always holds regular meetings to select cases, discuss and make recommendations for follow up based on findings from audit activities (awards and sanctions for actors), (4) $\mathrm{MCH}$ program planning is made by utilizing findings from audit activities, so it is expected to be oriented towards solving local problems. (5) Coaching is carried out by district / city health offices together with district / city hospitals (for medical technical aspects) carried out directly during audits or routinely, in the form agreed by the AMP team.(3) AMP teams need to be formed at the district/city level who always hold regular meetings to select cases, discuss and make recommendations for follow-up based on findings from audit activities (awards and sanctions for actors), (4) $\mathrm{MCH}$ program planning is made using the results findings from audit activities, so that they are expected to be oriented towards solving local problems, (5) Guidance is carried out by district / city health offices together with district / city hospitals (for medical technical aspects) carried out directly during audits or routinely, in a form agreed by AMP team.(3) AMP teams need to be formed at the district/city level who always hold regular meetings to select cases, discuss and make recommendations for follow-up based on findings from audit activities (awards and sanctions for actors), (4) MCH program planning is made using the results findings from audit activities, so that they are expected to be oriented towards solving local problems, (5) Guidance is carried out by district / city health offices together with district / city hospitals (for medical technical aspects) carried out directly during audits or routinely, in a form agreed by AMP team.(4) $\mathrm{MCH}$ program planning is made by utilizing findings from audit activities, so that it is expected to be oriented towards solving local problems, (5) Coaching is carried out by district / city health offices together with district / city hospitals (for medical technical aspects) carried out directly when audits or regularly, in the form agreed by the AMP team.(4) MCH program planning is made by utilizing findings from audit activities, so that it is expected to be oriented towards solving local problems, (5) Coaching is carried out by district/city health offices together with district / city hospitals (for medical technical aspects) carried out directly when audits or regularly, in the form agreed by the AMP team.And MDGs in the fourth point is to reduce child mortality and fifth item is to improve maternal health from the eight MDG goals.

Indonesian health development goals for 2005-2009 are improving public health by increasing access to health services that include, the increasing life expectancy of 66, two years to 67.9 years, infant mortality from 35 to 25 per 1,000 live births, the MMR decreased from 307 to 226 per 100,000 live births in 2010 and to 125 per 100,000 live births in 2015 (MDGs). 
The goal of achieving the Millennium Development Goal's (MDG) targets in points 4 and 5 to reduce the Maternal Mortality Rate (MMR) will be difficult to realize, unless efforts are made more intensively to accelerate the rate of decline. There are three late phases that are closely related to maternal and maternal mortality rates, namely: (1) being late one: being late to make a decision to seek help from the nearest health care provider or referring health services to other health services; (2) two late: late to arrive or arrive at the health service; (3) three late: late receiving care or arriving at adequate health services (DER, 2018).

The health of a pregnant woman is an important aspect to consider in a woman's life cycle because during her pregnancy there can be unexpected complications. Every pregnant woman will face risks that can threaten her life. Therefore, every pregnant woman needs care during her pregnancy (Salmah, 2013). Maternal mortality rate (MMR) is one indicator to look at a country's health status. The number of maternal deaths in developing countries is relatively high as happened in Sub-Saharan Africa and South Asia (WHO, 2015).

Pregnancy checks should be done as early as possible, as soon as a woman feels she is pregnant $(\mathrm{MOH}, 2012$ : 10). Every pregnancy, in its development has a risk of complications or complications. WHO has set standards in conducting antenatal care, at least 4 times during pregnancy. To see the number of pregnant women who have done antenatal care, namely from the results of achieving coverage indicators, one of which is the achievement of K1. The first visit (K1) is the first contact of pregnant women with competent health workers, to obtain integrated and comprehensive services according to standards. The first contact must be made as early as possible in the first trimester, preferably before Week 8. Pregnancy checks are very important to be done by all pregnant women to determine fetal growth and maternal health. Almost all pregnant women in Indonesia $(95,4 \%)$ had antenatal (K1) .

The cause of maternal death is direct labor disorders, such as bleeding by $28 \%$, infections by $11 \%$, eclampsia by $24 \%$, and parturition (long) jammed by $5 \%$. The possibility of maternal death in labor in a health center or hospital due to: the readiness of officers, the availability of materials and equipment and the attitude of officers. On the journey caused by transportation facilities, the level of difficulty and travel time, and deaths at home due to family decisions (knowledge, availability of funds, family and social and cultural busyness) and the availability of transportation (Saragih, and Nasution, 2018).

Maternal and child health contributes greatly to the nation's welfare indicators as measured by the Human Development Index. This indicator is an index of the combined results (composite index) of life expectancy (life expectancy), literacy rate (literate rate), and income per capita. Therefore maternal, newborn, and child health programs (KIBBLA) are long-term investments that provide benefits in improving family, community, regional and national welfare by increasing the Human Development Index reducing economic, family, regional and national economic burdens or losses. and create quality human resources (Siregar, 20 14).

Based on the results of a preliminary study at the Tirtoyudo Community Health Center, only 15 pregnant women found out that only 10 pregnant women knew about the K1 visit (first visit of a pregnant woman to health workers in Tribune 1) and 5 other pregnant women only knew that the first visit to a health worker could be done during -time. Based on the above background, which is the case in this study is the lack of achievement of K1 in 2018 in Puskesmas Tirtoyudo of 90, $7 \%$ of the target of $100 \%$. Therefore, researchers are interested in knowing the factors that influence the achievement of $\mathrm{K} 1$ in the working area of the Tirtoyudo Public Health Center.

\section{METHODS}

The approach in this study is a quantitative approach to the type of explanatory research. The study was conducted during the final 2 weeks in November 2019. The variables in this study were Knowledge of Pregnant Women (X1), Husband Support (X2), Role of Health Cadres (X3), and K1 Visits for the first 3 months (Y). The population in this study were all new pregnant women in October 2019 in the working area of the Tirtoyudo community health center, amounting to 105 with a total sample of 105 respondents. The sampling technique uses total sampling. The research instrument used was a questionnaire distributed to respondents with a measurement scale used was a Likert scale 1-4 while 
for the visit variable K1 (Y) used measurements with an ordinal scale of this matter. Data analysis uses logistic regression because the dependent variable is dummy (doing K1 under three months or not doing $\mathrm{K} 1$ under three months), then testing the hypothesis is done using logistic regression tests.

\section{RESULTS}

Inferential Analysis Test Results

1. Assessing the Overall Model ( Overall Model Fit

The first analysis carried out was to assess the overall model fit contained research data as research as shown in table 1.1 below:

Table 1.1 Comparison of Initial -2LL and Final -2LL

\begin{tabular}{|l|c|}
\hline -2Log Likelihood at the start ( block number $\mathbf{= 0}$ ) & 143,947 \\
\hline -2Log Likelihood at the end ( block number $\mathbf{~ 1 )}$ & 80,635 \\
\hline
\end{tabular}

As seen in table 5.4 that the comparison of the initial Log Likelihood value (block number $=0$ ) and the final Log Likelihood (block number $=1$ ) is 143,947 for the initial value and after the independent variables are entered in the regression model, the value of $-2 \mathrm{Log}$ Final likelihood (block number $=1$ ) is 80,635 .

Based on this output, there was a decrease in value between the initial and final Log Likelihoods of 63,312. Decreasing value of $-2 \log$ Likelihood can be interpreted that the addition of independent variables into the model can improve the fit model and show a better regression model or in other words the model hypothesized fit with the data (Ghozali, 2013: 340).

2. Logistic Regression Models Are Formed and Testing Hypotheses

The logistic regression model can be formed by looking at the estimated value of the parameters in Variables in the Equation in table 1.5 below:

\section{Table 1.4 Wald Test Results}

Variables in the Equation

\begin{tabular}{|ll|l|l|l|l|l|l|l|l|l|}
\hline & B & SE & Wald & df & Sig. & Exp (B) & \multicolumn{2}{|l|}{ 95\% CIfor EXP (B) } \\
\cline { 7 - 9 } & & & & & & & & Lower & Upper \\
\hline Knowledge_X1 & 1,767 & 0.119 & 7,695 & 1 & .004 & 5,851 & .92 & 372,505 \\
Step 1a & Husband_X2 & $-1,922$ & 0.645 & .528 & 1 & .467 & .146 & .001 & 26,086 \\
& Role_Cader_X3 & 7,636 & 0.322 & 5,286 & 1 & .22 & 2072,001 & 3,084 & 1392064,673 \\
& Constant & $-24,085$ & 0.494 & 19,215 & 1 & .000 & .000 & & \\
\hline
\end{tabular}

a. Variable (s) entered on step 1: Knowledge_X1, Husband_X2 Support, Role _Cadre_X3.

The regression model formed based on the estimated parameter values in Variahles in The Equation is as follows:

$$
\begin{aligned}
& \mathrm{Y}=-24,085 \alpha+1.767 \mathrm{X} 1+-1.922 \mathrm{X} 2+7.636 \mathrm{X} 3+0,494 \mathrm{e} \\
& \begin{array}{ll}
\text { Information }: \\
\alpha \quad=\text { Constant } \\
\mathrm{X} 1 \quad=\text { Knowledge of Pregnant Women } \\
\mathrm{X} 2 \quad=\text { Husband Support } \\
\mathrm{X} 3 \quad=\text { The Role of Health Cadres } \\
\mathrm{e} & =\text { Standard error }
\end{array}
\end{aligned}
$$

3. Hypothesis testing

Hypothesis testing is done by comparing the level of significance (sig) with an error rate $(\alpha)$ $=5 \%$ or 0,05 . Based on table 1.2 the results can be interpreted as follows: 
a. First Hypothesis Testing for knowledge pregnant women

In the knowledge variable pregnant women obtained a coefficient value of 1,767 with a significance level ( $\rho$-value) of $0.004>0,05$. Because the significant level is smaller than $\alpha=$ 0,05 then the 1 st hypothesis is accepted. This means that knowledge of pregnant women has a positive and significant effect on the decision of pregnant women to make their first visit (K1). So if the knowledge of pregnant women experiences an increase, the decision of pregnant women to make the first visit (K1) will be even greater. Or in other words, hypothesis of knowledge of pregnant accepted.

b. The first hypothesis testing for husband support

The husband support variable obtained a regression coefficient of -1.922. Husband support variable (X2) has a significance value (Sig.) 0.467 in the Wald test results table with a value of $\alpha$ (significance level) 0.05 meaning 0.467 is greater than alpha 0.05 or there is no significant influence. This means that husband's support has a negative and not significant effect on the decision of pregnant women to make the first visit (K1). Or in other words hypothesis of husband support is rejected.

c. First Hypothesis Testing for role of health cadres

In the role of the health cadre variable regression coefficient of 7.636 was obtained. Health cadre role variable (X3) hasa significance value (Sig.) 0.022 in the Wald test result table with values $\alpha$ (degree of significance) 0.05 that means 0.022 smaller than alpha 0.05 or there is a significant influence. This means that the role of health cadres has a positive and significant effect the decision of pregnant women to make a first visit (K1) will also be even greater. Or in other words, hypothesis of role of health cadres accepted

\section{DISCUSSION}

1. The Influence of Knowledge Factors of Pregnant Women on Decisions of Pregnant Women to Make First Visit (K1)

The results showed that the knowledge of pregnant women had a significant influence on the decision of pregnant women to make their first visit. This is indicated by the $p$-value of the variable knowledge of pregnant women at 0.004 or the level of significance possessed by the variable knowledge of pregnant women is smaller than $\alpha=0,05$. So it can be concluded that the knowledge of pregnant women significantly influence the decision of pregnant women to make the first visit (K1). Or in other words $\mathrm{H} 1$ is accepted.

Knowledge ( knowledge) is the result of "know" and this occurred after people perform sensing to a particular object. According to its function knowledge is a basic urge to be curious, to seek reasoning, and to organize its experiences (Agustini, Suryani, \& Murdani, 2013).

Respondents' knowledge about pregnancy and pregnancy check-ups provide an understanding of pregnant women about the importance of pregnancy visits . The knowledge possessed by the respondent includes information that increases respondents' confidence about the importance of a Pregnancy Visit visit, as well as the knowledge they have is able to encourage them to make a Pregnancy Visit visit. It is, as stated by Hoy and Miskel (2001) who argued that knowledge ( knowledge or science) is an essential part of human-accidents.

Human knowledge is obtained through its perception of the stimulus by means of the senses, the results of perception in the form of information will be stored in the memory system to be processed and given meaning, then the information is used ( retrieval) when needed. Thus the higher the level of respondents' knowledge about pregnancy and the examiner will have an effect on increasing the awareness and willingness of respondents to make a Pregnancy Visit visit. Besides the level of knowledge, there are also other factors that influence mother's behavior or actions in checking her pregnancy include: predisposing factors consisting of age, education, occupation, parity, and distance of pregnancy, enabling factors namely family income and need factors namely the condition of pregnant women (Sarminah, 2012).

The results of this study support the results of research conducted by Agustini, Suryani, and Murdani (2013) which states that there is a relationship between the level of knowledge and 
coverage of antenatal care where mothers with high levels of knowledge have the possibility of complete antenatal care coverage .

\section{The Effect of Husband's Support on the Decision of Pregnant Women to First Visit}

The results showed that husband's support had a negative and not significant influence on the decision of pregnant women to make their first visit. This is indicated by the p-value of the husband's support variable of 0.467 or the level of significance possessed by the husband's support variable greater than $\alpha=0,05$. So it can be concluded that the husband's support has a negative and not significant effect on the decision of pregnant women to make the first visit (K1). Or in other words $\mathrm{H} 2$ is accepted

Husband's support is the support given by the husband to his wife, a form of support in which the husband can provide psychological assistance in the form of motivation, attention and acceptance. Husband's support is a helpful relationship that has special value for the wife as a sign of positive ties (Goldberger \& Breznis, 2015).

Husband support and giving attention will help the wife in gaining self-confidence and selfesteem as a wife. With the attention of the husband makes the wife feel more confident, that he is not only right to be a wife, but the wife will also be happy to be (prospective) mother to the child she is carrying. Support given by others is very possible to contribute to one's psychological stability (Hersen , 1983 ).

Husband support and giving attention will help the wife in getting self-confidence and selfesteem as a wife. With the attention of the husband makes the wife feel more confident, that he is not only right to be a wife, but the wife will also be happy to be a (prospective) mother to her child (Adhi. Support given by others is very likely to contribute to the psychological stability of a person (Hersen, 1983 ).

The results of this study are in line with research conducted by Hafidz (2007) where there is a significant relationship between husband and family support for the use of antenatal care services. The same result was also found in a study conducted by Nurlaelah, which stated that there was a relationship between family support and antenatal care visits (Nurlaelah, 2014).

Even though there was support from the respondent's husband, he was still reluctant to come to the health facility to check the pregnancy, this was due to the lack of awareness from the respondent. Some respondents said that her husband only recommended regular pregnancy checkups, but her husband did not take her to a health facility so mothers became reluctant to visit health workers. This happened in a study conducted by Gabriellyn which showed that there was no relationship between husband support and regular antenatal visits (Pongsibidang, 2013).

Husband's support is important for wife's pregnancy because sometimes the wife is faced with situations of fear and loneliness, so the husband is expected to always motivate and accompany pregnant women. Besides the support given by the husband during a pregnant wife can also reduce anxiety and restore the confidence of expectant mothers in experiencing the process of pregnancy (Kusmiyati, 2010). This is consistent with the concept of standby husband that the husband's awareness of the danger signs of pregnancy and the readiness of a husband to accompany his wife to a health service for pregnancy checks is indeed expected at every pregnancy examination visit, the husband always accompanies his wife so that they know the condition of the pregnancy of his wife (Rahmawati, 2013).

\section{The Influence of the Health Cadre's Role on the Decision of Pregnant Women to First Visit}

The results showed that the role of health cadres had a positive and significant influence on the decision of pregnant women to make their first visit. This is indicated by the educational variable p-value of 0.022 or the level of significance possessed by the Health Cadre Role variable is smaller than $\alpha=0,05$. So it can be concluded that the role of health cadres has a positive and significant influence on the decision of pregnant women to make the first visit, so that if the role of the health cadre is greater then the decision of the thousand households to make the first visit will be even greater. Or in other words $\mathrm{H}_{2}$ is accepted . 
Antenatal Care is a service provided by preventive health workers in the form of antenatal care in accordance with antenatal care standards for pregnant women during pregnancy starting when the mother feels that she is pregnant with the aim of saving the mother and baby in pregnancy, childbirth and childbirth (MOH RI, 2008). Pregnancy checks that are in accordancewith the standard are performed at least four times, namely the first visit (K1) inthe first trimester, the second visit (K2) in the second trimester, the third visit (K3) and thefourthvisit(K4) in the third trimester. The type of antenatal care provided is in accordance withantenatal carestandardsin the form of weighing and measuring height, measuring blood pressure, Determination of nutritional status by measuring upper arm circumference, measuring uterine fundal height, determining fetal presentation and fetal heart rate (DJJ), screening for tetanus immunization status and administering TT (Tetanus toxoid) immunization if needed, administering Fe tablets, case management, and colloquium. (counseling) including planning for delivery and postpartum birth control (Depkes RI, 2008).

Anderson and Newman in 1973 stated that increased access occurs if service facilities are affordable. Affordability of health facilities that can be reached in a relatively short time especially if the distance is close to where users live (Amiruddin, 2011). The closer the home of a pregnant woman to a health service, the faster the time needed to get to the place so that more often to check her pregnancy. The results showed that there was no significant relationship between travel time and distance traveled with the use of Antenatal Care. This is because based on the observations of researchers in the field, it appears that health facilities are quite affordable by all communities in the three study sites in terms of travel time and distance. Lewin in the health belief model suggests that individuals will seek treatment in health services because they are motivated by perceived vulnerability, perceived seriousness, benefits received and obstacles experienced in their actions to fight their illnesses and cues or signs (Notoatmodjo, 2012).

Based on the results of the research that has been carried out, several conclusions are obtained, as follows:

a. Knowledge of pregnant women has a positive and significant influence on the decision of pregnant women to make a first visit (K1) for the first three months of pregnancy.

b. Husband's support does not have a significant influence on the decision of pregnant women to make the first visit (K1) the first three months of pregnancy.

The role of health cadres has a positive and significant influence on the decision of pregnant women to make the first visit (K1) the first three months of pregnancy

\section{CONCLUSION}

Based on the results of research that has been carried out, several conclusions are obtained, as follows:

1. The results showed that the Knowledge of Pregnant Women had a positive and significant influence on the decision of the Pregnant Mother to make the First Visit (K1) the first three months of pregnancy.

2. Husband's support does not have a significant influence on the decision of pregnant women to make the first visit (K1) the first three months of pregnancy

The role of health cadres has a positive and significant influence on the decision of pregnant women to make the first visit (K1) the first three months of pregnancy

\section{REFERENCES}

Agustini, N, Nunuk, S, Pancrasia, M.( 2013). Hubungan Antara Tingkat Pengetahuan Ibu Dan Dukungan Keluarga Dengan Cakupan Pelayanan Antenatal Di Wilayah Kerja Puskesmas Buleleng I. Jurnal Magister Kedokteran Keluarga, Vol 1, No 1, 2013 (hal 67-79).

Dewi, Peta Puspita, and Mujahidatul Musfiroh. (2013). Hubungan Pengetahuan Ibu Hamil Tentang Antenatal Care Dengan Frekuensi Kunjungan Antenatal Care Di Rumah Bersalin Wikaden Imogiri Bantul. Maternal 8.08. 
Nurlaelah. (2014). Faktor Yang Berhubungan Dengan Kunjungan Antenatal Care Di Wilayah Kerja Puskesmas Dungkait Kabupaten Mamuju. Fakultas Kesehatan Masyarakat Unhas.

Ompusunggu EM, Siagian IET, \& Umboh JML. (2013). Perilaku Ibu Hamil tentang Antenatal Care Puskesmas Bahu Kecamatan Malalayang Kota Manado. Manado: Jurnal e - Biomedik (eBM), vol.1,no.1, h.28-33.

Pongsibidang, Gabriellyn Sura and Zulkifli Abdulah.(2013). Faktor Yang Berhubungan Dengan Keteraturan Kunjungan Antenatal Di Wilayah Kerja Puskesmas Kapala Pitu Kabupatentoraja Utara.

Rahmawati, L. (2013). Analisis Faktor-Faktor yang Mempengaruhi Keberhasilan Pencapaian Cakupan K4 di Puskesmas Rowosari Semarang. Jurnal Kesehatan Masyarakat Universitas Diponegoro.

Raof A.M., \& Al-Hadithi, T.S.( 2011). Antenatal Care in Erbil City Iraq : Assessment of Information. Medical Jornal, Vol. 5. No. 1.

Saragih, R dan Nasution, R.S. (2018). Pengaruh Faktor Predisposisi, Pendukung Dan Penguat Terhadap Perawatan Kehamilan Di Kecamatan Raya Kahean Kabupaten Simalungun. Jurnal Bidan Komunitas Kebidanan, Vol. 1 No. 2 Hal. 76-85 I e-ISSN 2614-7874

Sarminah.. (2012). Faktor-Faktor yang Berhubungan dengan Kunjungan Antenatal Care Di Provinsi Papua Tahun 2010. Skripsi Universitas Indonesia Jakarta.

Siregar, A.R. (2014). Gambaran Kualitas Hidup pada Wanita Dewasa Awal Penderita Kanker Payudara. Jurnal Psikologia, Vol. 9. No. 3. Hal 82-88

Amiruddin R. (2011), Epidemiologi Perencanaan dan Pelayanan Kesehatan. Makassar: Masagena Press

Departemen Kesehatan RI.(2008). Profil kesehatan Indonesia 2007. Jakarta : Depkes RI Jakarta

Departemen Kesehatan RI.(2012). Profil Kesehatan Indonesia 2012. Jakarta: Kementrian Kesehatan RI; 2009

Depkes RI.( 2007). Keputusan Mentri Kesehatan RI No: 900/MENKES/VII/2007. Konsep Asuhan Kebidanan. Jakarta.

Ghozali, I. (2013). Aplikasi Analisis Multivariate dengan Program IBM SPSS 21 Update PLS Regresi. Semarang: Badan Penerbit Universitas Diponegoro.

Goldberger, Leo., and Breznitz, S. (2015). Handbook Of Stress: Theoritical and Clinical Aspect. London: Collier MacMilan Publishers.

Hersen, M. (1983). Behavioral Modivication : An Introductory. Text Book Oxford University.

Hoy, Wayne K, Miskel, Cecil G. (2011). Educational Administration. Mc. Graw Hill Company: New York.

Kusmiyati. (2010). Perawatan Ibu Hamil. Yogyakarta: Fitramaya.

Notoatmodjo, S.( 2014). Ilmu Perilaku Kesehatan. Jakarta: Rineka Cipta.

Widodo AD, Anggarani AM, Halim A, Maureen A, Landy B, Suarthana E. (2010). Pengetahuan, Sikap, dan Perilaku tentang Kehamilan, Persalinan serta Komplikasinya pada Ibu Hamil Nonprimigravida di RSUPN Cipto Mangunkusumo. Majalah Kedokteran Indonesia

World Health Organization (WHO). (2015. Global Tuberculosis Report 2015. Switzerland.

DER. (2018). Kematian Ibu Hamil Ternyata Disebabkan Faktor 4T dan 3T, Apa Saja? Diunduh pada 2 Maret 2020 dari https://malangvoice.com/kematian-ibu-hamil-ternyata-disebabkan-faktor-4tdan-3t-apa-saja/,. 